\title{
Emotion in Consumption Experience of Social Support; a Phenomenological Perspectives
}

\author{
Rosmanizah Derahman ${ }^{1, *}$, Md Akhir Sharift ${ }^{2}$ \\ ${ }^{1}$ Commerce Department, Politeknik Sultan Idris Shah, Malaysia \\ ${ }^{2}$ Management and Humanities Department, Universiti Teknologi Petronas, Malaysia
}

\begin{abstract}
The purpose of this paper is to explore the emotion of consumption experiences of social support. This phenomenological study employs a scientific research method with 17 informants using thematic analysis and three main themes become the central feeling and is the first interpretation of emotion in consumption experience. Three main themes were found (the feeling of uselessness, determination to self-control, and positive behavior) thru a study using purposive judgmental sampling.
\end{abstract}

\section{Introduction}

World's aging population is 617 Million in 2016 (National Institute on Aging, 2016), which also reaching two Billion in 2050. Currently, with an almost $12 \%$ increase in aging population aged 60 years and above, aging have been truly a phenomenon (United Nations, Population Division Department of Economic and Social Affairs, 2013). Most Asian countries are having an increasing number of an aging population due to low birth and mortality rate (Liao et al., 2014). Elderly by definition is someone aged more than 60 according to ASEAN and World Assembly of Ageing. In Malaysia, aging population aged 60 years and above is increasing and have reached 2.7 Million which is nearly $10 \%$ of its overall population by the year 2020 (Malaysia Department of Statistics, 2014). The statistic is driven by a longer life expectancy, shrinking of the family size as well as a reduced rate of fertility and mortality. The increasing population of an elderly is a good sign of a good community and excellence in modern medicine and a sign of a good elderly is when they are enjoying their quality of life.

However, today the life of an elderly is quite challenging. Elderly might experience an aging process whereby disability and declining of mobility to move would occur, and this would slowly expose themselves to a feeling of useless (Mollaoğlu, Tuncay, \& Fertelli, 2010) and the reduced self- care capacity would alter elderly views of their life.(Borg \& Blomqvist, 2006). Besides family institution has been regarded as a primary caregiver in Malaysia especially among Malay Muslim (Dahlan, Nicol, \& Maciver, 2010) and staying with own family members is such a perfect place for an elderly. However, an increase of nuclear family structure over of an extended family structure (Selvaratnam \& Tin, 2007),

*Corresponding author: rosmanizah@psis.edu.my 
(Y. Al-Kandari \& E. Crews, 2014) had put an elderly in a dilemma. Younger people prefer a nuclear family and quite reluctant to live in an extended family structure. This phenomenon would put an elderly into living alone which is highly exposed them to risk especially in the recent increased rate of criminal cases involving an elderly (Mohd Yusoff, 2009). Moreover with an increased case of neglected parents (Department of Social Welfare, 2014) and an increase of longevity would put an elderly into vulnerable (Onishi et al., 2010). Without an explanation, this situation would continuously occur, and this unnecessary behavior will continue to become trends. Further unnoticed on this behavior would jeopardize the elderly and if this persists, elderly will put themselves in physical and psychologically discontented.

In this modern world where the social relation is more vulnerable due to daily activities, value, conflicts and time management, getting satisfaction through experiential consumption is at risk. When Caru \& Cova (2007) described consuming experiences is not limited to the market, but it applies to an individual's daily life with and without market relation, this reflects perfectly to the life experiences of the elderly. It is because elderly consume more than we can ever imagine in their entire life and they would be the most required group who are believed to be able to explain deeply on consumption experiences. There would be some various dimension to look into consumer behavior but for today, superior customers' consumption experience become a priority (Rajagopal \& Castano, 2015). Consumption experience has been studied on a perception (Li, Dong, \& Chen, 2012) and yet to be explored on customers experience or actual behavior. Considering an elderly is rich with experiences throughout their life, understanding consumption experience thru their life experiences of emotion is deem required. Triantafillidou and Siomkos (2014a) have measured various emotional experiences through satisfaction, nostalgia intensity, word of mouth communication and behavioral intention but a deep understanding of it was suggested to be studied. Moreover, the ill-defined of consumption experience (Carù \& Cova, 2003a) require more understanding of the concept especially limited in social support consumption.

Social support is important to human being where it possibly could support physical and psychological of a human being (Uchino, Bowen, Carlisle, \& Birmingham, 2012) (Thompson, 2014) and even would cure and prevent cold (Cohen et al., 1997). As it is well known for its ability to improve psychological well-being (House, 1981), social support also crucial beneficial to physical health (Uchino, 2004). It is also known that social support contributes to encouraging outcomes (Heintzelman \& Bacon, 2015) and crucial to life. When consumption experience has become one of the element to understand consumer and behavior (Carù \& Cova, 2003b) this study was conducted to understand the emotion of consumption experiences of social support among an elderly.

Emotion has been accepted as a dominant role in consumer acts (Triantafillidou \& Siomkos, 2014b) and most studies have found the sign of it in consumer behavior (Richins, 1997). Emotion is a factor to behavioral such as thinking, actions, physical and mental health as well as decision making. (Izard C E, 2010) and has been acknowledged as one of the key factors in consumer behavior. However, there is limited evidence on the general theory to completely explain the emotional response to consumer behavior (Johnson \& Stewart, 2010). A statistical inquiry has been conducted to examine emotion management and found that emotion is controllable among an elderly (Gross et al., 1997) but they showed little expressive on determining the emotional sign. Therefore a need to understand the emotion of the elderly and recognize it in the consumption experience of social support would rather contribute. 


\section{Methodology}

Specifically, this study attempts to uncover the meaning of emotion in consumption experience of social support. This research design is based on the qualitative study. This phenomenological approach allows the researcher to explore the essence of the lived experiences of the participants about the phenomenon. Epistemologically, this research utilizes social constructivism worldviews and intends to understand the subjective meaning of elderly experiences.

\subsection{Sampling and Data Collection}

In this cross-sectional study, the researcher collects data using semi-structured openended questionnaire. The researcher seeks to establish the meaning of a phenomenon from views of participants through a face-to-face interview with at least 10 to 15 elderly in Malaysia and obtain thick and rich data (Gall et al, 2003) from an elderly. With nonprobability sampling and purposive judgmental sampling, this study has been conducted with the purpose of having rich data. This primary method of sampling involves selecting samples for a specific purpose in which researcher believes to be representatives ( Hair et al., 2007). This study also employed qualitative procedures with the semi-structured questionnaire to be a magnet for the wide range of interpretation based on questions adopted from DES 11-Differential Emotion Scale (Izard, 1977) on human emotions and Richins (1997). Thus with an average of two hours length of the interview session, all 15 informants and two pilot study have been conducted and successfully contributed to the data. The informants vary from various backgrounds, location, educational level, financial and marital status, gender and other demographic details.

Table 1: Informants Profiles

\begin{tabular}{|c|c|c|c|c|c|c|c|c|}
\hline Bil & $\begin{array}{l}\text { Pseudony } \\
\mathrm{ms}\end{array}$ & Gender & Age & Education & Location & Status & $\begin{array}{l}\text { No } \\
\text { Of } \\
\text { Childre } \\
\mathrm{n}\end{array}$ & $\begin{array}{l}\text { Financial } \\
\text { Sources }\end{array}$ \\
\hline 1 & $\begin{array}{l}\text { Kak Pah } \\
\text { (pilot) }\end{array}$ & $\mathrm{F}$ & 62 & $\begin{array}{l}\text { Islamic } \\
\text { Education }\end{array}$ & $\begin{array}{l}\text { Sub } \\
\text { Urban }\end{array}$ & Married & 10 & Children \\
\hline 2 & $\begin{array}{l}\text { Mak Zai } \\
\text { (pilot) }\end{array}$ & $\mathrm{F}$ & 65 & No school & $\begin{array}{l}\text { Sub } \\
\text { Urban }\end{array}$ & $\begin{array}{l}\text { Single } \\
\text { Mother }\end{array}$ & 4 & Children \\
\hline 1. & $\begin{array}{l}\text { Mak } \\
\text { Batu } \\
\text { Gajah }\end{array}$ & $\mathrm{F}$ & 66 & No School & $\begin{array}{l}\text { Sub } \\
\text { Urban }\end{array}$ & $\begin{array}{l}\text { Single } \\
\text { Mother }\end{array}$ & 4 & $\begin{array}{l}\text { Small } \\
\text { Business }\end{array}$ \\
\hline .2 & $\begin{array}{l}\text { Mak Su } \\
\text { Salmo } \\
\end{array}$ & $\mathrm{F}$ & 66 & No School & Urban & $\begin{array}{l}\text { Single } \\
\text { Mother }\end{array}$ & 5 & Children \\
\hline 3. & Pak Teh & $\mathrm{M}$ & 89 & $\begin{array}{l}\text { Islamic } \\
\text { Education }\end{array}$ & Rural & Married & 4 & $\begin{array}{l}\text { Government } \\
\text { allowance }\end{array}$ \\
\hline .4 & Kak Min & $\mathrm{F}$ & 61 & $\begin{array}{l}\text { Primary } \\
\text { School } \\
\end{array}$ & Urban & $\begin{array}{l}\text { Single } \\
\text { Mother }\end{array}$ & 3 & Baitulmal \\
\hline 5. & $\begin{array}{l}\text { Mak } \\
\text { Suraya }\end{array}$ & $\mathrm{F}$ & 68 & $\begin{array}{l}\text { Secondary } \\
\text { school }\end{array}$ & Urban & $\begin{array}{l}\text { Single } \\
\text { Mother } \\
\text { (Divorce) }\end{array}$ & 3 & Children \\
\hline 6. & Mama & $\mathrm{F}$ & 65 & $\begin{array}{l}\text { Secondary } \\
\text { School }\end{array}$ & Urban & $\begin{array}{l}\text { Single } \\
\text { Mother }\end{array}$ & 2 & Children \\
\hline .7 & Ustaz $\mathrm{Pa}$ & $\mathrm{M}$ & 68 & $\begin{array}{l}\text { Higher } \\
\text { Education }\end{array}$ & $\begin{array}{l}\text { Sub } \\
\text { Urban }\end{array}$ & Married & 5 & Pensions \\
\hline .8 & Kak Leha & $\mathrm{F}$ & 63 & No School & Urban & Single & 0 & Still Working \\
\hline 9. & $\begin{array}{l}\text { Kak } \\
\text { Sidah }\end{array}$ & $\mathrm{F}$ & 65 & $\begin{array}{l}\text { Secondary } \\
\text { School }\end{array}$ & Urban & Married & 5 & Husband \\
\hline 10 & $\begin{array}{l}\text { Kak } \\
\text { Tipah }\end{array}$ & $\mathrm{F}$ & 64 & $\begin{array}{l}\text { Secondary } \\
\text { School }\end{array}$ & Urban & $\begin{array}{l}\text { Single } \\
\text { Mother }\end{array}$ & 5 & Pensions \\
\hline
\end{tabular}




\begin{tabular}{|c|c|c|c|c|c|c|c|c|}
\hline . & & & & & & & & \\
\hline 11 & $\begin{array}{l}\text { Mak Nik } \\
\text { Limah }\end{array}$ & $\mathrm{F}$ & 89 & No School & Rural & $\begin{array}{l}\text { Single } \\
\text { Mother }\end{array}$ & 4 & Still working \\
\hline 12 & $\begin{array}{l}\text { Mak Su } \\
\text { Sakinah }\end{array}$ & $\mathrm{F}$ & 68 & $\begin{array}{l}\text { Primary } \\
\text { School }\end{array}$ & Rural & Married & 5 & Still working \\
\hline 13 & $\begin{array}{l}\text { Chek } \\
\text { Setek }\end{array}$ & $\mathrm{M}$ & 81 & No School & Rural & $\begin{array}{l}\text { Single } \\
\text { Father }\end{array}$ & 5 & Children \\
\hline 14 & $\begin{array}{l}\text { Acik } \\
\text { Klang }\end{array}$ & $\mathrm{F}$ & 64 & $\begin{array}{l}\text { Secondary } \\
\text { School }\end{array}$ & Urban & Married & 5 & Husband \\
\hline 15 & $\begin{array}{l}\text { Acik } \\
\text { Proton }\end{array}$ & $\mathrm{F}$ & 79 & No School & Urban & $\begin{array}{l}\text { Single } \\
\text { Mother }\end{array}$ & 4 & Felda \\
\hline 16 & Kak Yam & $\mathrm{F}$ & 63 & $\begin{array}{l}\text { Higher } \\
\text { Education }\end{array}$ & $\begin{array}{l}\text { Sub } \\
\text { Urban }\end{array}$ & Married & 3 & $\begin{array}{l}\text { Government } \\
\text { allowance }\end{array}$ \\
\hline 17 & $\begin{array}{l}\text { En. } \\
\text { Zainal }\end{array}$ & $\mathrm{M}$ & 72 & $\begin{array}{l}\text { Higher } \\
\text { Education }\end{array}$ & Urban & Married & 1 & Pensioner \\
\hline
\end{tabular}

\subsection{Data Analysis}

This solo researcher conducted the study and follows all procedures of qualitative research (Yin, 2011). Nearly 30 transcriptions were prepared and transcribed by the researcher using software Atlas ti. The transcription later was coded in a cleaning process before reassembling process were implemented. More than 250 codes assembled and later were disassembled into fewer codes (Yin, 2011). Atlas-ti. 7.5.17 is used to manage the data from an interview, field note and reflective journal. Member check was performed including with the transcription prepared especially which were transcribed from the local dialect. Member check then validated the report about the transcription. Discussion with an expert in the field of study and method used was also performed through email. They were given the codes and quotation to check and validate the match. Finally, a few themes emerged with the deductive themes and fulfill the research question.

\section{Results and Discussion}

The findings are presented in the content form in a thematic analysis which relies on spoken words as well as nonverbal material (Smith, 2000) through personal interview words based on informants' lives stories. This approach is pertinent to 'real life problems' which is explored through individual experiences. Analysis revealed three major themes of an emotion of consuming social support. Each theme derived from various reassembling and disassembling codes.

\section{Themes: The feeling of valueless, determine to control self and action}

This theme describes the meaning informant brings when consuming social support from various parties; family, neighbors, community, government and others like pets. In this situation, informants convey particularly the feeling of valueless. Informants always refer the social support provider as their own children, whether the children are together or separately stay. Even though they are married, or single, social support provider would be 
the children or someone perceived as their children. Thus the emotion of feeling valueless is closely related to the category of their feeling of being ignored, hurts, having the crisis, feel pity or unable to keep memories. In the context of Malay Muslim, the feeling of valueless would occur during their everyday lives and each time of visit. In Malay Muslim, it is obviously good if the children can stay together with their parents even after their marriage. For those who stay separately, they normally visit their parents during weekends or just after their working hours. Even some of them asked the old parents to keep an eye on their children. But some would rather forbid the grandchildren from visiting due to crisis occurred. Thus the informants experienced a feeling of useless. Some informants feel ignored, for instance, "I was transferred to safe place in government school when the flood eroded my whole house, my daughter, she doesn't bother to come and take me to her home, instead she doesn't even come looking for me in the center". Other reported, "My daughter speaks harshly, she just said what she wants". Most informants feel hurt, ignored, pity, unable to keep memories which meant the feeling of invaluable. I15 who is 78 years old who lives on the second floor of five floors flat reported how she only could burst into tears after all her properties were being stolen by her own brother and her other children took away all of her trophies as a winner in a Quran Recital in State Level. She is also lost her late mother and husband at the same time and did not own anything to help her keep sweet memories in her life. "I have nothing to keep me in touch with all the good memories, I only have this aged body to remind me of that". Thus I09 reported about the strategies she used to manage the feeling, "I don't want to ask anything, if not it will create other problems, better I ignore my feeling" and III also emphasize on and said "Just let it be, Allah is mighty, let me ignore that and keep quiet, pray and let her be, I always pray for her". Accordingly, informants are so wise to deal with the emotion and they forgive. I16 said, “ there is a reason why God made us losing our ability to hear a sound, see clearly and talk fluently to made us senseless and keep happy even with what our support do".

Table 2: Results

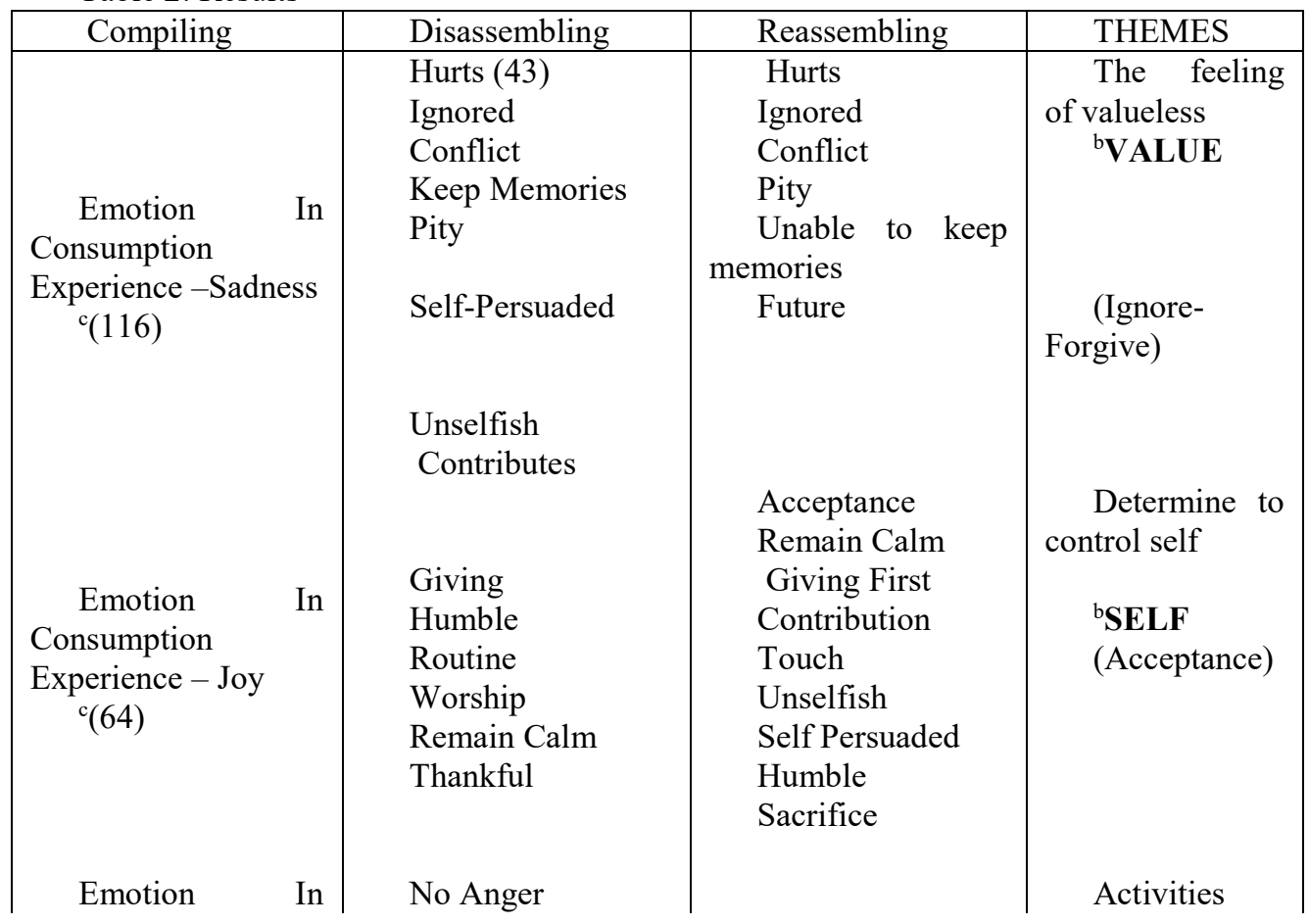




\begin{tabular}{|c|c|c|c|}
\hline \multirow{4}{*}{$\begin{array}{l}\text { Consumption } \\
\text { Experience - Anger } \\
\quad{ }^{\mathrm{c}}(40)\end{array}$} & Sulking & Routine & \multirow{8}{*}{$\begin{array}{l}{ }^{\mathrm{b}} \mathbf{A C T I O N S} \\
\text { (Pray) }\end{array}$} \\
\hline & Acceptance & Future & \\
\hline & Conflict & Financial & \\
\hline & Hurts & Worship & \\
\hline Emotion & Hurt Others & & \\
\hline Consumption & No Fear & & \\
\hline Experience - Fear & Future & & \\
\hline${ }^{c}(36)$ & & & \\
\hline Fmotion & Giving & Worship & \multirow{4}{*}{$\begin{array}{l}{ }^{\mathrm{b}} \text { ISLAMIC } \\
\text { TEACHING }\end{array}$} \\
\hline Consumption & Sacrifice & Manage & \\
\hline Experience - Love & Touch & No Fear & \\
\hline 'c(28) & & $\begin{array}{l}\text { No Anger } \\
\text { No Joy }\end{array}$ & \\
\hline
\end{tabular}

Notes: ${ }^{a}$ The number in the parentheses represent the frequency of quotations, ${ }^{b}$ codes derived inductively and ${ }^{c}$ codes derived deductively

The second theme represents the informants view about their self-determination to keep the bad feeling to themselves. They want to try to accept, remain calm, more giving, contributing, unselfish, self-persuaded, humble and sacrifice. I01 shared, "when seeing the children success, I am happy, is worth it, even I was in difficult times". I02 emphasized," I don't want to think, I leave all to God" and I01 suggested, "we shouldn't dig into people's lives, if they treated us bad, maybe they have problems with themselves". Thus most of them accept and realized that all of these are God's will and it was a test to them too.

This third theme supports the original deductive theme. Most informants perceive that our actions will help us to manage the feelings such as performs all the routines such work and chores and worships. Thus I14 reported about the strategies she used to manage the feeling;

"I wake up early in the morning, perform my worship, do all my routines, that makes me have no feeling, no happiness, no sorrow", but teaching neighbors with al-Quran, reclaim my joy". Accordingly, all informants referred to Islamic teaching to ease them managing their emotion in later life. Despite the feeling of sadness, joy, anger, fear and love which carries the most codes from nine emotion, inductively appears three other new emerging themes; feeling of invaluable, self and action.

\section{Discussion And Conclusion}

Result in the qualitative thematic analysis indicated that the emotion in consumption experience of social support can be described in many forms. Accordingly, this study explains the details of sadness, joy, anger, fear and love among elderly.

The present study confirmed that most leading basic emotion study (Mehrabian \& Russell, 1974), (Plutchik, 1980), (Richins, 2008), (Izard, 2009) are worth to describe. The results of the present study generate the results from the actual informants in the smaller context. Informants come from the variation of backgrounds, locations, age, educational level, financial stability, family size and health condition. All of them experiencing the emotion and perceive it as significant to their daily lives. In this Malay Muslim context, the informants live in a diversity of people but appreciate similar culture. The study emphasizes on the consuming of social support which is vital to informants' later life. Most informants affected by the experienced emotion of consumption but many of them figured out how to 
manage it effectively. Accordingly, each emotion represents deductive meaning as well as some emerging categories such as contributing, worship, calm, sacrifice, physical contact, sulking and self-persuaded. Despite some authors believe that emotion should be abandoned away out of theory (Izard, 2010), the study describes the significance of value, self, and action towards sustaining emotion in consuming social support.

In addition, emotion was influenced by 'mental consideration' (Dixon, 2012), thus coping strategy would be just a matter of self-control. Thus most informants suggested and clarified the way they managed it by keeping the feeling inside them. As old folks in a home, informants keep to prioritize the overall atmosphere of a home, tried to accommodate a 'good home' and this made them control themselves over other emotional factors. But despite the negative emotion which requires self-control, informants also have control over positive emotion via Islamic teaching.

As the definition of emotion is not generally accepted and each researcher is free to bring their own operational term (C. E. Izard, 2010), the study conveyed emotion thru Theory of Social Support closely to society and suggested some actions to be taken to manage emotion of elderly while providing social support. Regardless what Wierzbicka (2010) did to defies definition of by Izard or other scholars have found a significant concept of emotion to consumers, the study is not to confirm it directly. In fact, the study enhanced understanding of the five selected emotion which can reflect on informants and social support providers. In particular, some important implications in understanding the emotion of consumption of social supports among elderly have been described in the context of Malay Muslim society.

\section{References}

[1] Borg, C., Hallberg, I. r, \& Blomqvist, K., "Life satisfaction among older people with reduced self-care capacity; the relationship to social, health and financial aspects", Journal of Clinical Nursing, 15(5), pp 607-618, (2006)

[2] Carù, A., \& Cova, B. Revisiting consumption experience: A more humble but complete view of the concept. Marketing Theory, 3(2), 267-286, (2003a).

[3] Dahlan, A., Nicol, M., \& Maciver, D., "Elements of Life Satisfaction Amongst Elderly People Living in Institutions in Malaysia: A Mixed Methodology Approach", Hong Kong Journal of Occupational Therapy, 20(2), pp 71-79, (2010)

[4] Gall, M. ., Borg, W. ., \& Gall. J.PEducational Research: An Introduction (p. 7th Edition, White Plains, NY, Longman), (2003).

[5] Hair, J. F., Arthur H, M., Philip Samouel, \& Mike Page.. Research Method for Business (pp. 1-448), (2007)

[6] Heintzelman, S. J., \& Bacon, P. L. "Relational self-construal moderates the effect of social support on life satisfaction", Personality and Individual Differences, 73, pp 72-77, (2015a),

[7] Heintzelman, S. J., \& Bacon, P. L. "Relational self-construal moderates the effect of social support on life satisfaction”, Personality and Individual Differences, 73, pp 72-77, (2015b),

[8] House, J. S. Work Stress and Social Support. (Addison-Wesley, Ed.) (1983rd ed.), (1981).

[9] Izard, C. E.. Izard Emotion theory 2009. Annu. Rev. Psychol, 60, 1-25, (2009)

[10] Izard C. E. The Many Meanings/Aspects of Emotion: Definitions, Functions, Activation, and Regulation. Emotion Review, 2(4), 363-370, (2010). doi:10.1177/1754073910374661 
[11] Liao, C.-C., Li, C.-R., Lee, S.-H., Liao, W.-C., Liao, M.-Y., Lin, J, Lee, M.C. (2014), "Social support and mortality among the aged people with major diseases or ADL disabilities in Taiwan: A national study", Archives of Gerontology and Geriatrics, (2014). [12] Li, M., Dong, Z. Y., \& Chen, X. Factors influencing consumption experience of mobile commerce; A study from experiential view. Internet Research, 22(2), 120-141. (2012). doi:10.1108/10662241211214539

[13] Mohd Yusoff, J. J., "Jenayah dalam keluarga: penderaan dan pengabaian warga tua di Malaysia”, International Conference on Corporate Law (ICCL), (June). (2009)

[14] Mollaoğlu, M., Tuncay, F. Ö., \& Fertelli, T. K., "Mobility disability and life satisfaction in elderly people”, Archives of Gerontology and Geriatrics, 51(3), pp 115-9, (2010)

[15] Onishi, C., Yuasa, K., Sei, M., Ewis, A. A., Nakano, T., Munakata, H., \& Nakahori, Y., "Determinants of life satisfaction among Japanese elderly women attending health care and welfare service fa-facilities", JMed Invest, 57, pp 69-80, (2010).

[16] Plutcik, R.. A general psycho evolutionary theory of emotion. Emotion: Theory, Research, and Experience, 1, 3-33. (1980) doi:CiteULike-article-id:8791184

[17] Rajagopal, \& Castano, R. Understanding Consumer Behavior and Consumption Experiences. Hersyey PA : IGI Global. (2015). doi:10.4018/978-1-4666-7518-6.ch002

[18] Richins, M. L. Measuring Emotion in Consumption Experience. Journal of Consumer Research, 24(September). (1997a).

[19] Selvaratnam, D. P., \& Tin, P. B. "Lifestyle of the elderly in rural and urban Malaysia", Annals of the New York Academy of Sciences, 1114, pp 317-325. (2007),

[20] Thompson, R. a. "Social support and child protection: Lessons learned and learning", Child Abuse \& Neglect. Vol 41, pp 19-29. (2014),

[21] Triantafillidou, A., \& Siomkos, G. Consumption experience outcomes: satisfaction, nostalgia intensity, word-of-mouth communication and behavioral intentions. Journal of Consumer Marketing, 31, 526-540. (2014a). doi:10.1108/JCM-05-2014-0982

[22] Uchino, B. N., Bowen, K., Carlisle, M., \& Birmingham, W. "Psychological pathways linking social support to health outcomes: a visit with the "ghosts" of research past, present, and future”, Social Science \& Medicine (1982), 74(7), pp 949-57, (2012),

[23] Uchino, B. N. Social support and physical health: Understanding the health consequences of relationships. Current perspectives in psychology, (2004).

[24] United Nations, Population Division Department of Economic and Social Affairs. World Population Ageing 2013, (2013)

[25] Wierzbicka, a. On Emotions and on Definitions: A Response to Izard. Emotion Review, 2(4), 379-380, (2010). doi:10.1177/1754073910374664

[26] Y. Al-Kandari, Y., \& E. Crews, D. "Age, social support and health among older Kuwaitis”, Quality in Ageing and Older Adults, 15(3), pp 171-184, (2014).

[27] Yin, R. K. Qualitative Study, From start to finish, Guildford Press, London, (2011). 